\title{
The relationship between chronic viral hepatitis and erectile dysfunction in male patients more than 65 years old
}

\section{Yaş üzerindeki erkek hastalarda kronik virral hepatit ille erektil disfonksiyon arasındaki ilişki}

\author{
Sedlat Taştemur ${ }^{1}$, *Ahmet Aktaş²
}

${ }^{1}$ Ankara City Hospital, Department of Urology, Ankara, Turkey

${ }^{2}$ Sivas Cumhuriyet University Medical School, Department of Internal Medicine, Sivas, Turkey

Corresponding author: Ahmet Aktaş, MD, Sivas Cumhuriyet University Medical School, Department of Internal Medicine, Sivas, Turkey

E-mail: ahmetaktas0142@hotmail.com

Received/Accepted: December 03, 2020 /December 17, 2020

Conflict of interest: There is not a conflict of interest.

\section{SUMMARY}

Objective: Erectile dysfunction is defined as the incomplete failure of penile erection for satisfying sexual intercourse. Its incidence is quite high in male patients over 65 years of age. Many diseases, such as Diabetes Mellitus, obesity, and psychiatric diseases, affect erectile dysfunction. In our study, we aimed to show the relationship between chronic viral hepatitis and erectile dysfunction in male patients over 65 years of age.

Method: A single-center retrospective study. Sixty-five male patients over 65 years old, 35 chronic viral hepatitis, 30 healthy controls were included in our study. Patients with comorbidities facilitating erectile dysfunction such as diabetes mellitus, obesity, and psychiatric disease were excluded from our study.

Results: Erectile dysfunction was found in 49 of the 65 patients included in our study. There was no significant difference between HDL, Triglyceride, AST, ALT, GGT, LDH, Total Protein, and Albumin levels in the control group with hepatitis ( $p>0.05$ ). On the other hand, age and erectile dysfunction were found statistically significantly higher in the group with hepatitis ( $p<0.001, p=0.002$, respectively). IIEF, Total cholesterol and LDL were statistically significantly higher in the Control group $(p<0.001$, $p=0.01$ and $p=0.02$, respectively).

Conclusions: The incidence of erectile dysfunction was higher in male patients over 65 years of age with chronic viral hepatitis compared to the control group. There was a significant relationship between erectile dysfunction and chronic viral hepatitis and advanced age.

Keywords: Erectile dysfunction, chronic viral hepatitis, over 65 years old
Sedat Taştemur

Ahmet Aktaş

ORCID IDs of the authors:

S.T. 0000-0003-0534-2520

A.A. $0000-0001-9464-0700$

\section{ÖZET}

Amaç: Erektil disfonksiyon, cinsel ilişkiyi devam ettirebilmek için penil ereksiyonunun başarısızlığı olarak tanımlanmaktadır. 65 yaş üstü erkek hastalarda görülme sıklığı oldukça yüksektir. Diabetes Mellitus, obezite ve psikiyatrik hastalıklar gibi birçok hastalık erektil disfonksiyonu etkiler. Çalışmamızda 65 yaş üstü erkek hastalarda kronik viral hepatit ile erektil disfonksiyon arasındaki ilişkiyi göstermeyi amaçladık.

Yöntem: Tek merkezli retrospektif bir çalışma. Çalışmamıza 35' i kronik viral hepatitli, 30 sağlıklı kontrol olmak üzere toplam da 65 yaş üstü altmış beş erkek hasta dahil edildi. Diabetes mellitus, obezite, psikiyatrik hastalık gibi erektil disfonksiyonu kolaylaştıran komorbiditeleri olan hastalar çalışma dışı bırakıldı. 
Bulgular: Calışmamıza dahil edilen 65 hastanın 49'unda erektil disfonksiyon saptandı. Hepatit grubunda ve kontrol grubunda HDL, Trigliserid, AST, ALT, GGT, LDH, Total Protein ve Albümin düzeyleri arasında anlamlı fark yoktu (p> 0.05). Öte yandan, yaş ve erektil disfonksiyon hepatiti olan grupta istatistiksel olarak anlamlı yüksek bulundu (sırasıyla $\mathrm{p}<0,001, \mathrm{p}=0,002)$. IIEF, Total kolesterol ve LDL, kontrol grubunda istatistiksel olarak anlamlı derecede daha yüksekti (sirasiyla $\mathrm{p}<0.001, \mathrm{p}=0.01$ ve $\mathrm{p}=0.02$ ).

Sonuç: Kronik viral hepatitli 65 yaş üstü erkek hastalarda erektil disfonksiyon insidansı kontrol grubuna göre daha yüksekti. Erektil disfonksiyon ile kronik viral hepatit ve ileri yaş arasında önemli bir ilişki vardı.

Anahtar sözcükler: Erektil Disfonksiyon, kronik viral hepatit, 65 yaş üstü

\section{INTRODUCTION}

Failure to achieve or maintain an adequate penis erection to achieve satisfactory sexual activity is defined as Erectile dysfunction (ED). Since sexual functions are an essential component of quality life, $\mathrm{ED}$; has become an increasingly important topic ${ }^{1}$.

According to the Massachusetts Male Aging Study (MMAS), the frequency of ED is $52 \%$ in men aged 40-70 2 . Turkish Society of Andrology, based on his research in Turkey, was found in $69.2 \%$ of ED over 40 years of age ${ }^{3}$.

It is known that there are many interrelated factors in the emergence and continuation of ED. These etiological causes are divided into three as psychogenic, organic, and mixed type. Organic and psychogenic etiologies are intertwined in many cases in ED may create difficulties in the differential diagnosis. In the past, very few of the ED cases were thought to be of organic origin, but now $80 \%$ of ED cases are known to be responsible for organic causes. Emerging due to an organic etiology, ED generally causes anxiety in the person and causes ED to progress further. Psychogenic causes in ED etiology; Personality disorders such as performance anxiety, obsessive disorder, anxiety disorders, depression, and psychotic disorders. Organic factors include various causes such as cardiovascular disease, genitourinary disease, diabetes mellitus, malignancies, thyroid diseases, and hypertension ${ }^{4,5}$.

$\mathrm{ED}$ is a more common problem as the age progresses due to increased hypertension, hyperlipidemia, smoking, Diabetes Mellitus (DM), obesity, and vascular diseases with advanced age. Studies have shown that drugs such as phosphodiesterase inhibitors (PDE5-I) for ED are not used alone in the treatment. However, the treatment of diseases such as DM and obesity increases the frequency of ED, and cessation of diseases such as DM, obesity, and cessation of smoking. Some evidence suggests that ED can be significantly improved not only by some medications but also by direct treatment of risk factors. All this happens due to an improvement in endothelial functions ${ }^{6}$.
There is a close relationship between ED, endothelial dysfunction, and aging. Risk factors that seem insignificant such as hypoxia, inflammation, oxidative stress, are also associated with endothelial dysfunction and ED. ED problems originating from organic etiologies account for about $80 \%$ of cases, and the most common pathophysiology of ED is vascular disease. According to previous studies, ED is an early symptom of endothelial dysfunction in the presence or absence of cardiovascular risk factors. Therefore, patients with ED have an increased risk of cardiovascular, and ED may appear as a sentinel symptom in patients with unknown cardiovascular disease. However, the ED rate also increases after 60 , independent of comorbidities such as coronary artery disease, diabetes, and hypertension. Also, older men are often affected by various diseases, and the medications they use for these diseases potentially worsen sexual function and increase the frequency of $\mathrm{ED}^{7,8}$.

Most studies have been done on liver diseases and sexual dysfunction in patients with alcoholic liver cirrhosis, decompensated cirrhosis, or those who are waiting for a liver transplant. Patients with advanced liver disease, such as cirrhosis, often resort to causes such as decreased libido, ED, testicular atrophy, and infertility, which are the clinical features of hypogonadism ${ }^{9,10}$.

Some studies have stated that the severity of liver cirrhosis is related to the degree of ED. However, there are very few studies on ED in patients with viral diseases associated with viral hepatitis, especially in the early stage of chronic hepatitis or cirrhosis. However, ED has remained in a few limited studies that are often incomparable in patients with chronic viral hepatitis, as it uses different patient sampling methods and questionnaires. Few studies have evaluated the relationship between depression and ED in patients with chronic viral hepatitis ${ }^{11,12}$.

In this study, we aimed to show whether there is a relationship between chronic liver disease due to viral hepatitis and ED in male patients over 65 . 


\section{MATERIAL AND METHODS}

Ankara City Hospital admitted between January 1, 2019- January 1, 2020, 200 men over age 65 are made of the patient's file browsing. Chronic viral hepatitis was detected in 45 patients. Patients with diabetes, coronary artery disease, psychiatric illness, malignancy, abnormal thyroid function tests, smoking were excluded from the study. We included 35 patients with chronic viral hepatitis and 30 healthy controls from male patients over 65 . Patients' age, Aspartate Aminotransferase (AST), Alanine Aminotransferase (ALT), Gamma Glutamyl Transferase (GGT), Lactate Dehydrogenase (LDH), Total Cholesterol, HighDensity Lipoprotein (HDL), Low-Density Lipoprotein (LDL), Triglyceride, total protein, albumin, IIEF score, and whether there is erectile dysfunction were recorded.

\section{IIEF Score}

There have been several interrogation questionnaires developed to evaluate ED. However, the most widely accepted questionnaire was the International Erectile Function Index (IIEF). IIEF is an interrogation questionnaire developed by Rosen to question various sexual functions. With this questionnaire, 15 questions that determine the participants' erectile function, orgasmic function, sexual desire, sexual satisfaction, and general satisfaction status are asked. These 5 different sexual function areas are scored according to the answers received (Table $1)^{13}$.

Table 1: IIEF score assessment (13).

\begin{tabular}{|l|c|c|}
\hline \multicolumn{1}{|c|}{ Area } & Questions & Total score \\
\hline Erectile function & $1,2,3,4,5,15$ & $1-30$ \\
& & $0-10=$ serious \\
& & $11-16=$ moderate \\
& & $\begin{array}{c}\text { 17-21 }=\text { slight-moderate } \\
22-25=\text { mild } \\
\end{array}$ \\
& & $26-30=$ no \\
\hline Orgasmic function & 9,10 & $0-10$ \\
\hline Sexual desire & 11,12 & $2-10$ \\
\hline Sexual satisfaction & $6,7,8$ & $0-15$ \\
\hline General satisfaction & 13,14 & $2-10$ \\
\hline
\end{tabular}

IIEF, widely used worldwide, has been translated into more than thirty languages. This includes Turkish. Translation and validation of IIEF to Turkish were done by Andrology Association in $2002^{3}$.

\section{STATISTICS}

Statistical Package for Social Sciences (SPSS), version 22.0 (SPSS Inc. Chicago, USA) computer package program was used for statistical analysis of the research data. In the descriptive statistics section, categorical variables are presented as numbers, percentages, and continuous variables are presented with mean \pm standard deviation. The consistency of continuous variables to normal distribution was evaluated using visual (histogram and probability graphs) and analytical methods (Kolmogorov-Smirnov / Shapiro-Wilk tests). If the data of continuous variables show normal distribution as a result of the normality analysis, the Independent Sample T-test was used for comparative analysis between two groups. MannWhitney U test was used if it did not show normal distribution.
A Chi-square test was used in comparison analysis for categorical variables between independent groups. Univariate analysis of risk factors predicting erectile dysfunction was performed.

In this study, the statistical significance level was accepted as $\mathrm{p}<0.05$.

\section{RESULTS}

The average age of patients included in our study was $66.03 \pm 6.13$, total cholesterol $181.81 \pm 40.89$, triglyceride $140.82 \pm 63.41$, LDL-Cholesterol $104.26 \pm 37.87$, HDL-Cholesterol $44.34 \pm 11,06$, AST $28,44 \pm 23,4$, ALT $24,52 \pm 11,72$, GGT 44,73 $\pm 61,31, \mathrm{LDH} 192,44 \pm 38,18$, total protein $73,81 \pm$ 10,51, albumin 73 The mean score of $81 \pm 10.51$, IIEF-15 was $17.89 \pm 8.4$, the number of erectile dysfunction was 49 (76.6\%) (Table 2).

Average age in chronic viral hepatitis group is $68.59 \pm 5.06$, total cholesterol $171.82 \pm 39.41$, triglyceride $128.82 \pm 55.2$, LDL-Cholesterol 94.97 \pm 37.07 , HDL-Cholesterol $42.76 \pm 11,72$, AST $27.97 \pm 14.84$, ALT $24.21 \pm 11.94$, GGT $54.18 \pm$ $80.1, \mathrm{LDH} 197.68 \pm 45.53$, total protein $72.71 \pm$ 
4.37, albumin The mean score of $44 \pm 5.85$, IIEF15 was $14.03 \pm 8.43$, and the number of erectile dysfunctions was $32(91.4 \%)$. The mean age of the control group was $62.93 \pm 5.95$, total cholesterol $193.93 \pm 40.03$, triglyceride $155.39 \pm 70.41, \mathrm{LDL}-$ Cholesterol 115.54 \pm 36.33 , HDL-Cholesterol $46.25 \pm 10,08$, AST $29 \pm 31.1$, ALT $24.89 \pm 11.65$, GGT $33.25 \pm 20.07$, LDH $186.07 \pm 26.12$, total protein $75.14 \pm 14.93$, albumin 45 , The mean score of $46 \pm 2.39$, IIEF- 15 was $22.57 \pm 5.56$, and the number of erectile dysfunctions was 17 (60.7\%). The mean age and number of erectile dysfunctions were statistically significantly higher in the chronic viral hepatitis group compared to the control group ( $\mathrm{p}<0.001, \mathrm{p}=0.002$ ). IIEF-15 score means total cholesterol means and LDL-Cholesterol mean statistically significantly lower in the chronic viral hepatitis group compared to the control group ( $\mathrm{p}$ $<0.001, \mathrm{p}=0.01, \mathrm{p}=0.02)($ Table 3$)$.
When the patients were divided into two groups according to the erectile dysfunction status, the mean age in the group with erectile dysfunction was higher than the group without erectile dysfunction $(67.34 \pm 5.48 ; 61.93 \pm 6.43 \mathrm{p}=0.002)$. In the group with erectile dysfunction, the IIEF-15 score was lower than the group without erectile dysfunction $(14.91 \pm 7.45 ; 27.2 \pm 1.61 \mathrm{p}<0.001)$. Total cholesterol, triglyceride and ALT levels were lower in the group with erectile dysfunction compared to the group without erectile dysfunction $(p=0.01, p=0.05, p=0.02)$. The number of patients with chronic viral hepatitis was significantly higher in the group with erectile dysfunction compared to the group without erectile dysfunction (32 (91.4\%), $3(8.6 \%) \mathrm{p}=0.002)$ (Table 4).

Age and chronic viral hepatitis status were statistically significant as risk factors for erectile dysfunction $(\mathrm{p}=0.007, \mathrm{p}=0.005)($ Table 5).

Table 2: Demographic data and laboratory values of patients included in the study

\begin{tabular}{|l|c|}
\hline & MEAN \pm SE \\
\hline Age, year & $66.03 \pm 6,13$ \\
\hline IIEF Score & $17,89 \pm 8,4$ \\
\hline Erectile Dysfunction, n(\%) & $49(\% 76,6)$ \\
\hline Total Cholesterol (mg/dL) & $181,81 \pm 40,89$ \\
\hline HDL (mg/dL) & $44,34 \pm 11,06$ \\
\hline LDL (mg/dL) & $104,26 \pm 37,87$ \\
\hline Triglycerides (mg/dL) & $140,82 \pm 63,41$ \\
\hline AST (U/L) & $28,44 \pm 23,4$ \\
\hline ALT (U/L) & $24,52 \pm 11,72$ \\
\hline GGT (U/L) & $44,73 \pm 61,31$ \\
\hline LDH (U/L) & $192,44 \pm 38,18$ \\
\hline Total protein (g/L) & $73,81 \pm 10,51$ \\
\hline Albumin (g/L) & $44,66 \pm 6,64$ \\
\hline se: standard deviation & \\
\hline Aminon & \\
\hline
\end{tabular}

AST; Aspartate Aminotransferase, ALT; Alanine Aminotransferase, GGT; Gamma Glutamyl Transferase, LDH; Lactate Dehydrogenase, HDL; High Density Lipoprotein, LDL; Low Density Lipoprotein. 
Table 3: Evaluation of demographic and laboratory data of patients with hepatitis and the control group.

\begin{tabular}{|c|c|c|c|}
\hline & Hepatitis $(\mathbf{n}=\mathbf{3 5})$ & $\begin{array}{c}\text { Control Group } \\
(\mathbf{n}=\mathbf{3 0})\end{array}$ & $\mathbf{P}$ \\
\hline $\begin{array}{l}\text { Age, year } \\
\text { mean } \pm \text { se }\end{array}$ & $68.59 \pm 5,06$ & $62,93 \pm 5,95$ & $<0.001^{1}$ \\
\hline $\begin{array}{l}\text { IIEF Score } \\
\text { mean } \pm \text { se }\end{array}$ & $14,03 \pm 8,43$ & $22,57 \pm 5,56$ & $<0.001^{1}$ \\
\hline Erectile Dysfunction, n(\%) & $32(\% 91,4)$ & $17(\% 60,7)$ & $0,002^{3}$ \\
\hline Total Cholesterol (mg/dL) & $171,82 \pm 39,41$ & $193,93 \pm 40,03$ & $\mathbf{0 , 0 1 ^ { 2 }}$ \\
\hline HDL (mg/dL) & $42,76 \pm 11,72$ & $46,25 \pm 10,08$ & $0,2^{2}$ \\
\hline LDL (mg/dL) & $94,97 \pm 37,07$ & $115,54 \pm 36,33$ & $0, \mathbf{0 2}^{2}$ \\
\hline Triglycerides (mg/dL) & $128,82 \pm 55,2$ & $155,39 \pm 70,41$ & $0,1^{1}$ \\
\hline AST (U/L) & $27,97 \pm 14,84$ & $29 \pm 31,1$ & $0,19^{1}$ \\
\hline$\overline{\operatorname{ALT}(\mathbf{U} / \mathbf{L})}$ & $24,21 \pm 11,94$ & $24,89 \pm 11,65$ & $0,6^{1}$ \\
\hline GGT (U/L) & $54,18 \pm 80,1$ & $33,25 \pm 20,07$ & $0,9^{1}$ \\
\hline LDH (U/L) & $197,68 \pm 45,53$ & $186,07 \pm 26,12$ & $0,2^{2}$ \\
\hline Total protein $(\mathrm{g} / \mathrm{L})$ & $72,71 \pm 4,37$ & $75,14 \pm 14,93$ & $0,8^{1}$ \\
\hline Albumin (g/L) & $44 \pm 5,85$ & $45,46 \pm 2,39$ & $0,8^{1}$ \\
\hline
\end{tabular}

AST; Aspartate Aminotransferase, ALT; Alanine Aminotransferase, GGT; Gamma Glutamyl Transferase, LDH; Lactate Dehydrogenase, HDL; High Density Lipoprotein, LDL; Low Density Lipoprotein.

Table 4: Comparison of Patients According to Erectile Dysfunction Status

\begin{tabular}{|c|c|c|c|}
\hline & $E D+(n=49)$ & ED- $(n=16)$ & $\mathbf{P}$ \\
\hline $\begin{array}{l}\text { Age, year } \\
\text { mean } \pm \text { se }\end{array}$ & $67,34 \pm 5,48$ & $61.93 \pm 6,43$ & $0,002^{2}$ \\
\hline $\begin{array}{l}\text { IIEF Score } \\
\text { mean } \pm \text { se }\end{array}$ & $14.91 \pm 7,45$ & $27,2 \pm 1,61$ & $<0.001^{1}$ \\
\hline Erectile Dysfunction, n(\%) & $174,43 \pm 37,44$ & $204,93 \pm 43,88$ & $0,01^{2}$ \\
\hline Total Cholesterol (mg/dL) & $43,53 \pm 11,18$ & $46,87 \pm 10,62$ & $0,2^{2}$ \\
\hline HDL $(\mathbf{m g} / \mathrm{dL})$ & $100,04 \pm 35,51$ & $117,47 \pm 43,12$ & $0,1^{2}$ \\
\hline LDL (mg/dL) & $131,66 \pm 58,09$ & $169,53 \pm 72,58$ & $0,05^{1}$ \\
\hline Triglycerides (mg/dL) & $30,51 \pm 26,55$ & $21,93 \pm 6,6$ & $0,3^{1}$ \\
\hline AST (U/L) & $24,28 \pm 13,16$ & $25,27 \pm 5,3$ & $\mathbf{0 , 0 2} 2^{1}$ \\
\hline $\operatorname{ALT}(\mathbf{U} / \mathbf{L})$ & $47,89 \pm 69,5$ & $34,8 \pm 19,28$ & $0,7^{1}$ \\
\hline GGT (U/L) & $193 \pm 41,17$ & $190,67 \pm 27,85$ & $0,8^{2}$ \\
\hline LDH (U/L) & $74,17 \pm 11,74$ & $72,67 \pm 5,17$ & $0,4^{1}$ \\
\hline Total protein $(g / L)$ & $44,36 \pm 5,06$ & $45,6 \pm 2,94$ & $0,7^{1}$ \\
\hline Hepatitis n,\% & $32(\% 91,4)$ & $3(\% 8,6)$ & $0,002^{3}$ \\
\hline
\end{tabular}

AST; Aspartate Aminotransferase, ALT; Alanine Aminotransferase, GGT; Gamma Glutamyl Transferase, LDH; Lactate Dehydrogenase, HDL; High Density Lipoprotein, LDL; Low Density Lipoprotein 
Table 5: Univariate regression analysis in patients with age and hepatitis with erectile dysfunction

\begin{tabular}{|l|c|c|c|}
\hline \multicolumn{4}{|c|}{ univariate } \\
\hline Age & OR & $\mathbf{9 5 \%}$ CI & p \\
\hline Hepatitis & 1.2 & $1.05-1.37$ & 0,007 \\
\hline \multicolumn{4}{|l|}{ OR: Odds ratio CI: Confidence Interval } \\
\hline
\end{tabular}

\section{DISCUSSION}

Common causes of erectile dysfunction include many diseases, including heart disease, hypertension, dyslipidemia, atherosclerosis, and metabolic diseases such as diabetes mellitus. Again, neurological diseases such as ischemic cerebrovascular disease, Parkinson's disease, and multiple sclerosis are other potential causes of erectile dysfunction. Some physical trauma and injuries, mainly affecting the pelvic area and spinal cord, can cause nerve damage, leading to erectile dysfunction. All these comorbid conditions are widespread in elderly patients. However, in elderly patients, we should understand the effects of many different diseases or treatments on erectile function and the effects of the same diseases ${ }^{14}$.

Rosen et al. The IIEF score developed by has excellent reliability and sensitivity to assess male erectile dysfunction ${ }^{13}$. In this study, we used the IIEF score to evaluate erectile function in male patients with chronic viral hepatitis infection and found that $91.4 \%$ of patients had erectile dysfunction. In a previous study by Ferri et al. reported an incidence of $88 \%$ erectile dysfunction in HCV positive patients. In the study in which Şimşek et al. ${ }^{15}$ demonstrated the prevalence of erectile dysfunction in patients with chronic viral hepatitis, they detected $50 \%$ erectile dysfunction in patients with chronic viral hepatitis. Our result also showed that erectile dysfunction is high in patients with chronic viral hepatitis, as in the study by Ferri et al. ${ }^{16}$.

According to the results of our study, erectile dysfunction was found significantly higher in the chronic viral hepatitis group compared to the control group. The reported prevalence of ED in patients with chronic viral hepatitis ranges from $14 \%$ to $78 \%$. In our study, we found $91.4 \%$ erectile dysfunction in patients with chronic viral hepatitis over 65 years of age. According to the Turkish Society of Andrology study, erectile dysfunction was found to be $69.2 \%$ in men over 40 years of age. However, as we exclude confounding factors that can cause erectile dysfunction, the actual diffusion difference between erectile dysfunction patients and the general population may vary. We found that age, total cholesterol, and LDL-Cholesterol, $\mathrm{ALT}$, and triglyceride levels were associated with erectile dysfunction in patients with chronic viral hepatitis.

Some predictions have been made in previous studies for the high ED prevalence in patients with chronic viral hepatitis. In a study, it was stated that chronic viral hepatitis might be associated with erectile dysfunction with various complex mechanisms leading to increased oxidative stress, inflammation, insulin resistance, and apoptosis. Chronic inflammation accompanied by increased C-reactive protein (CRP) levels reduces nitric oxide synthesis in endothelial cells. Thus, it explains the relationship between erectile dysfunction and hepatitis-related liver disease due to endothelial dysfunction ${ }^{17,18}$.

Many medical conditions have been associated with erectile dysfunction ${ }^{19}$. After excluding many conditions such as diabetes mellitus, obesity, and psychiatric diseases facilitating erectile dysfunction, we found a significant relationship between age and IIEF-15 score and erectile dysfunction. Chung et al. ${ }^{11}$ reported that there was no significant difference in the frequency of the previous diagnosis of hepatitis between the group with erectile dysfunction and the control group in a study they conducted in a population over 69 years old. They stated that older men increased the frequency of erectile dysfunction due to age-related factors unrelated to hepatitis, such as lower testosterone levels and higher peripheral vascular resistance. In our study, we found that erectile dysfunction significantly higher in patients with chronic viral hepatitis compared to the healthy control group.

\section{CONCLUSION}

In our study, we found a high incidence of age and erectile dysfunction in male patients over the age 
of 65 compared to the control group in the chronic viral hepatitis group. However, we see the low number in our study group as the limitation of our study. Comprehensive clinical studies are needed to investigate the pathophysiology of erectile dysfunction in patients with chronic viral hepatitis above 65 .

Ethic committie approval: The ethics committee and work permits from Ankara City Hospital were taken with the number E1-20-1138.

Conflict of Interest Statement: No conflict of interest was declared by the authors.

\section{Contributions of the authors to the article}

S.T set up the main idea and hypothesis of the study. A.A and S.T developed the theory and edited the material method section. A.A and S.T made the evaluation of the data in the results section. The discussion part of the article was written by A.A and S.T, S.T reviewed and made the necessary corrections and approved. In addition, all authors discussed the entire study and approved its final version.

\section{REFERENCES}

1. Svatikova, A., \& Kopecky, S. L. (2020). Why and How Cardiovascular Screening Should Be Implemented in Sexual Medicine Practice: Erectile Dysfunction and Cardiovascular Disease. The Journal of Sexual Medicine, 17(6), 1045-1048.

2. Levy, J. (2002). Impotence and its medical and psychosocial correlates: results of the Massachusetts Male Aging Study. The British Journal of Diabetes \& Vascular Disease, 2(4), 278-280.

3. Kendirci, M., Asci, R., Yaman, Ö., Cayan, S., Orhan, I., Usta, M. F., ... \& Kadioglu, A. (2014). Prevalence of male pelvic dysfunction: results from the Turkish society of andrology male sexual health study group. Andrology, 2(2), 219-224.

4. Shamloul, R., \& Ghanem, H. (2013). Erectile dysfunction. The Lancet, 381(9861), 153-165.

5. Cazzaniga, W., Capogrosso, P., Montorsi, F., Salonia, A., URI, I. O. S. R., \& Boeri, L. (2020). Erectile Dysfunction. Urologic Principles and Practice, 159.

6. Rusiecki, L., Zdrojowy, R., Gebala, J., Rabijewski, M., Sobieszczańska, M., Smoliński, R., ... \& Kałka, D. (2020). Sexual health in Polish elderly men with coronary artery disease: importance, expectations, and reality. Asian Journal of Andrology.
7. Konstantinovsky, A., Tamir, S., Katz, G., Tzischinsky, O., Kuchersky, N., Blum, N., \& Blum, A. (2019). Erectile Dysfunction, Sleep Disorders, and Endothelial Function. The Israel Medical Association journal: IMAJ, 21(6), 408411.

8. Wan, Z. H., Zhang, Y. J., Chen, L., Guo, Y. L., Li, G. H., Wu, D., \& Wang, Y. (2019). G protein-coupled receptor kinase 2 inhibition improves erectile function through amelioration of endothelial dysfunction and oxidative stress in a rat model of type 2 diabetes. Asian journal of andrology, 21(1), 74.

9. Ma, B. O., Shim, S. G., \& Yang, H. J. (2015). Association of erectile dysfunction with depression in patients with chronic viral hepatitis. World Journal of Gastroenterology: WJG, 2l(18), 5641.

10.Kim, M., Kim, S. Y., Rou, W. S., Hwang, S. W., \& Lee, B. S. (2015). Erectile dysfunction in patients with liver disease related to chronic hepatitis B. Clinical and molecular hepatology, 21(4), 352.

11.Chung, S. D., Keller, J. J., Liang, Y. C., \& Lin, H. C. (2012). Association between viral hepatitis and erectile dysfunction: A population-based case-control analysis. The Journal of Sexual Medicine, 9(5), 1295-1302.

12.Fusco, F., D'Anzeo, G., Rossi, A., Sciorio, C., Buonomo, A. R., d'Emmanuele di Villa Bianca, R., ... \& Gentile, I. (2013). Erectile dysfunction in patients with chronic viral hepatitis: a systematic review of the literature. Expert opinion on pharmacotherapy, 14(18), 25332544.

13.Rosen, R. C., Riley, A., Wagner, G., Osterloh, I. H., Kirkpatrick, J., \& Mishra, A. (1997). The international index of erectile function (IIEF): a multidimensional scale for assessment of erectile dysfunction. Urology, 49(6), 822-830.

14.Gareri, P., Castagna, A., Francomano, D., Cerminara, G., \& De Fazio, P. (2014). Erectile dysfunction in the elderly: an old widespread issue with novel treatment perspectives. International journal of endocrinology, 2014.

15.Simsek, I., Aslan, G., Akarsu, M., Koseoglu, H., \& Esen, A. (2005). Assessment of sexual functions in patients with chronic liver disease. International journal of impotence research, 17(4), 343-345. 
16.Ferri, C., Bertozzi, M. A., \& Zignego, A. L. (2002). Erectile dysfunction and hepatitis C virus infection. Jama, 288(6), 698-699.

17.Huyghe, E., Kamar, N., Wagner, F., Capietto, A. H., El-Kahwaji, L., Muscari, F., ... \& Rostaing, L. (2009). Erectile dysfunction in end-stage liver disease men. The journal of sexual medicine, 6(5), 1395-1401.

18.Vergniol, J., Duc, S., Hou, G., Hiriart, J. B., Foucher, J., Chenus, F., ... \& De Lédinghen, V.
(2016). Sexual quality of life is impaired in patients with chronic hepatitis C. International Journal of Impotence Research, 28(2), 68-73.

19.Paternostro, R., Heinisch, B. B., Reiberger, T., Mandorfer, M., Schwarzer, R., Seeland, B., ... \& Ferlitsch, A. (2018). Erectile dysfunction in cirrhosis is impacted by liver dysfunction, portal hypertension, diabetes and arterial hypertension. Liver International, 38(8), 14271436. 